\title{
INDOOR SURVEYING WITH TERRESTRIAL PHOTOGRAMMETRY: A CASE STUDY FOR SIRCALI MASJID
}

\author{
${ }^{1}$ Lütfiye KARASAKA, ${ }^{2}$ Hakan KARABÖRK, ${ }^{3}$ Bilgehan MAKİNECI, ${ }^{4}$ Atiye ONURLU, ${ }^{5}$ Gizem İŞLER \\ 1,2,3,4,5 Selcuk University, Engineering Faculty, Department of Geomatic Engineering, Konya, Turkey \\ 1lutfiye@selcuk.edu.tr, 2hkarabork@selcuk.edu.tr, 3bilgehanmakineci@selcuk.edu.tr, \\ ${ }^{4}$ onurlu_atiye@hotmail.com, 5isler_gizem@hotmail.com
}

(Geliş/Received: 08.11.2018; Kabul/Accepted in Revised Form: 06.12.2018)

\begin{abstract}
In this study, indoor 3D modeling study of Sırçalı Masjid in located in the Karatay district of Konya province was carried out by using the terrestrial photogrammetry method. The Masjid was built in the single-domed masjid type of Seljuk period. The single- domed masjid type is a type of building with square or rectangular base area. However, in order for the dome design to fit in to a square or rectangular sub-structure, a transitional element is needed. The Turkish Triangle was used as transition elements of facilitate the transition from a square-shaped sub-structure to a circular structure in Sırçalı Masjid. With this study, the dome transition elements, which are difficult to model in terms of classical architectural survey, have been modelled successfully by the terrestrial photogrammetry technique in a short time. It has also been proven that terrestrial photogrammetry can be used effectively in the indoor 3D modelling projects.
\end{abstract}

Key Words: Indoor architecture, Indoor 3D modelling, Masjid or Mosque architecture, Terrestrial photogrammetry

\section{Yersel Fotogrametri ile İç Mekân Ölçme: Örnek Çalışma Sırçalı Mescit}

ÖZ: Bu çalışmada Konya ili Karatay ilçesinde bulunan Sırçalı Mescidi'nin iç mekân 3B modelleme çalışması, yersel fotogrametri yöntemi kullanılarak gerçekleştirilmiştir. Mescit, tek kubbeli mescit tipi Selçuklu dönemine ait bir eserdir. Tek kubbeli mescit, kare veya dikdörtgen şeklinde bir taban alanı ile yapı arasını bağlayan elemana sahip bir mescit tipidir. Bununla birlikte, kubbe tasarımının bir kare veya dikdörtgen alt yapıya uyması için bir geçiş elemanına ihtiyaç vardır. Türk Üçgeni Sırçalı Mescidi'nde kare biçimli bir alt yapıdan dairesel bir yapıya geçişi kolaylaştırmak için geçiş elemanları olarak kullanılmıştır. Bu çalışmada, klasik mimari yüzey araştırması açısından modellenmesi zor olan kubbe geçiş elemanlarının, kısa sürede yersel fotogrametri tekniği ile modellenebilir olduğu gösterilmiştir. Ayrıca, iç mekân fotogrametrisinin iç mekân 3B modelleme projelerinde etkin bir şekilde kullanılabileceği kanıtlanmıştır.

Anahtar Kelimeler: İ̧̧ mekân mimarisi, İç mekân 3B modelleme, Mescit veya Cami mimarisi, Yersel fotogrametri

\section{INTRODUCTION}

Anatolian lands have many valuable cultural heritages in herited from the past to present because they have been home to many different cultures and civilizations throughout history. Nowadays restoration and documentation studies are carried out in order to keep these works alive and transfer them to next generations. For this purpose, classical or modern techniques are preferred. The digital 
photogrammetric techniques which are the modern measurement and evaluation techniques, offers economical, practical, accurate and 3D solutions for architectural surveys. When the 3D modelling studies are examined in the literature, it is generally observed that weight is given to external facade surveying of works. However, many of the works hosted by Anatolia are also actually rich with interior architecture. Numerous Masjid and Mosque examples can be given of these works. In particular, the domed interior spaces geometry of mosques and masjids provide information about the architectural and engineering knowledge of the period they were built. Nowadays, it is quite difficult and time consuming to modelling and documentation of these special architectures with traditional measurement methods. It is possible to document by 3D modelling for difficult objects with the developments in software and computer technology. In this context, close range photogrammetry technique has been used as one of the most effective and efficient methods (Karabork et al., 2015). The aim of this study is to extract the transitional components to dome using close range photogrammetry technique.

\section{CASE STUDY AND METHODS}

\section{The Sırçalı Masjid}

The building is located at the Nakipoğlu neighbourhood in the Karatay district of Konya. There is no information anywhere on the structure who is the builder and the construction date it was made (Konyal1, 1997). It is understood that according to the architectural style that was built towards to ends of the XIII th century (Önder, 1971). These small size buildings with one dome built in between neighbourhoods. The building, which was built as a masjid, is still used as a masjid today. These masjids are covered with a dome with changing a square or semi-square plan, and there are dome switch elements between the dome and the substructure (Turan and Yaldız, 2018). The structure is located of three places mosques group as a structure with a square plan, an open end communal aerial to the east and minaret. The last community place of the masjid was built with a vault and the harim part is covered with a dome. In the harim part, a triangular band that makes a corner group was used as a dome transition member (Turan, 2018).

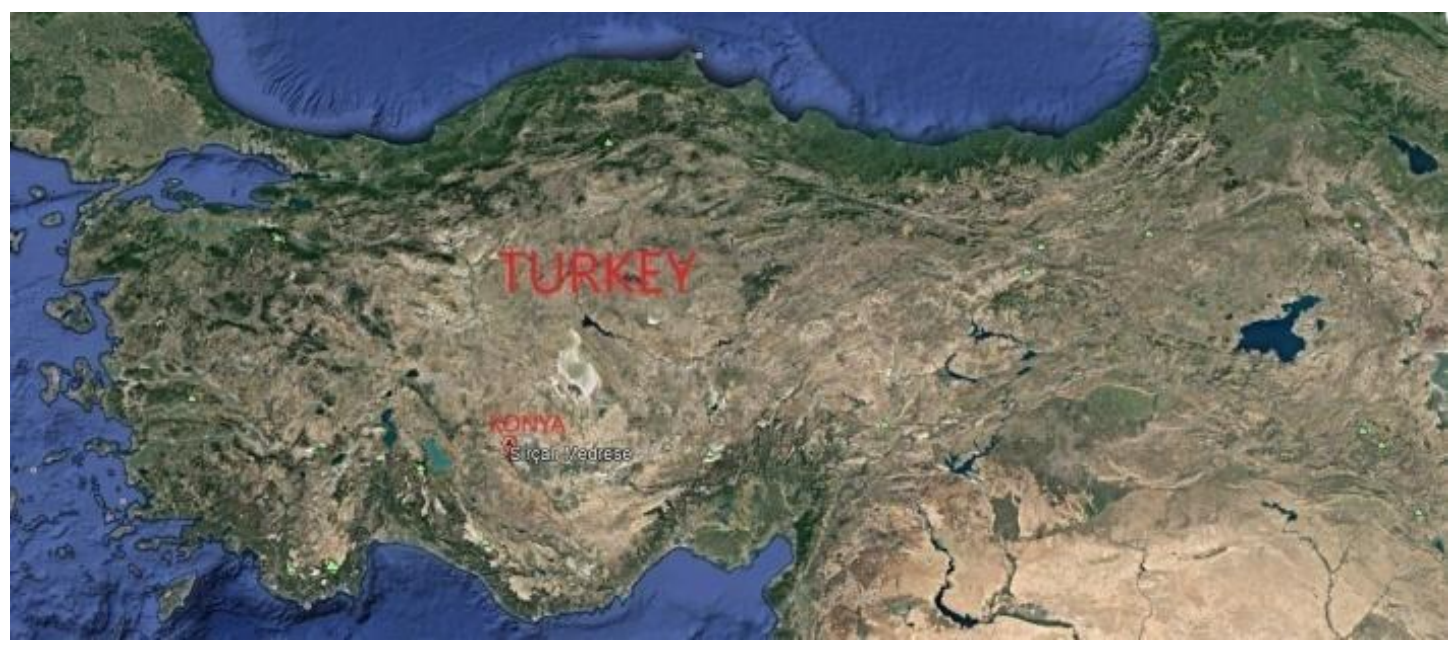

Figure 1. The location of study area on google maps 


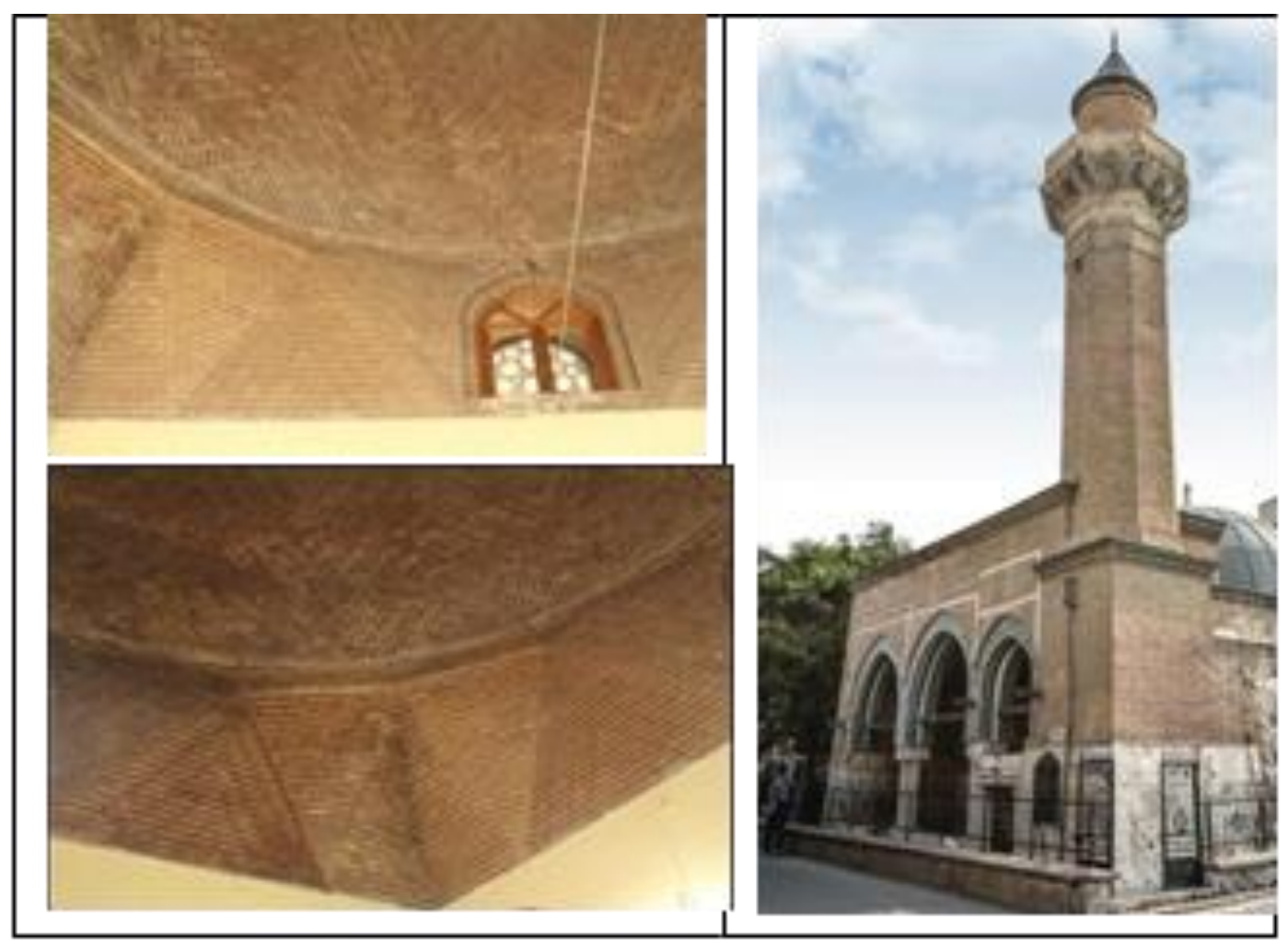

Figure 2. Sırçalı Masjid

\section{Data Acquisition and 3D Modelling}

The photogrammetric workflow in general is as shown below. With these process steps, 3D models are obtained by matching similar points on pairs of images taken from different angles according to the epipolar geometry principle.

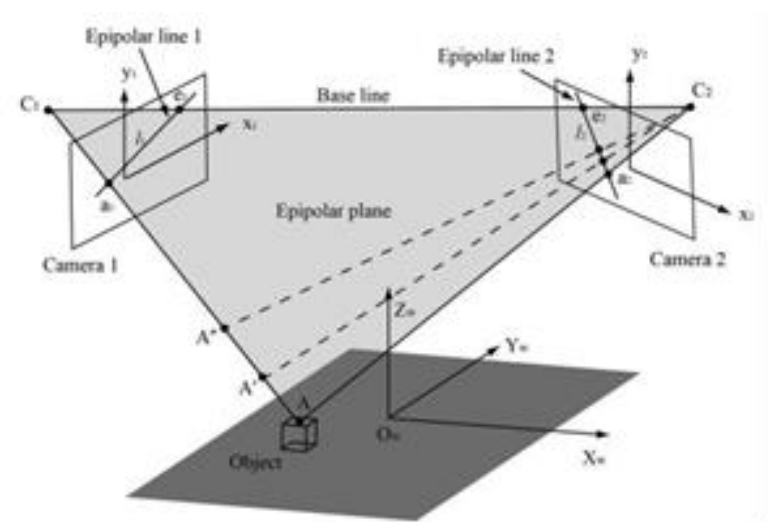

Figure 3. Epipolar geometry (Nakazawa and Samara, 2014)

In the epipolar geometry (Fig. 3), the epipolar plane consisted by the two projection centres and the object point defines the epipolar lines as its intersections with the two image planes (Jebara et al.,, 1999) 
Table 1. Photogrammetric workflow

\begin{tabular}{|l|}
\hline \\
$\cdot$ 1. Planning survey \\
$\bullet$ 3. Acquire images \\
$\bullet$ 4. to measure of the control points on the object \\
$\cdot$ 5. Process images/Triangulated and orient images \\
$\cdot 6$. Deliverables/stereo model, textures, or-thoimages, object/surface models
\end{tabular}

If a non-metric camera is used, the camera calibration is required to obtain reliable and accurate metric information from stereo image pairs. In this study, the Sircalı Masjid were photographed by using Canon EOS 650D digital cameras. The simple test pattern known as calibration paper consisting grid points was used for calibration. This calibration paper is fixed on a plane and photographed from different angles and positions. The camera interior orientation parameters were determined using the camera calibration process of the Photomodeler Scanner software. The parameters related to the camera calibration are given in table 2.

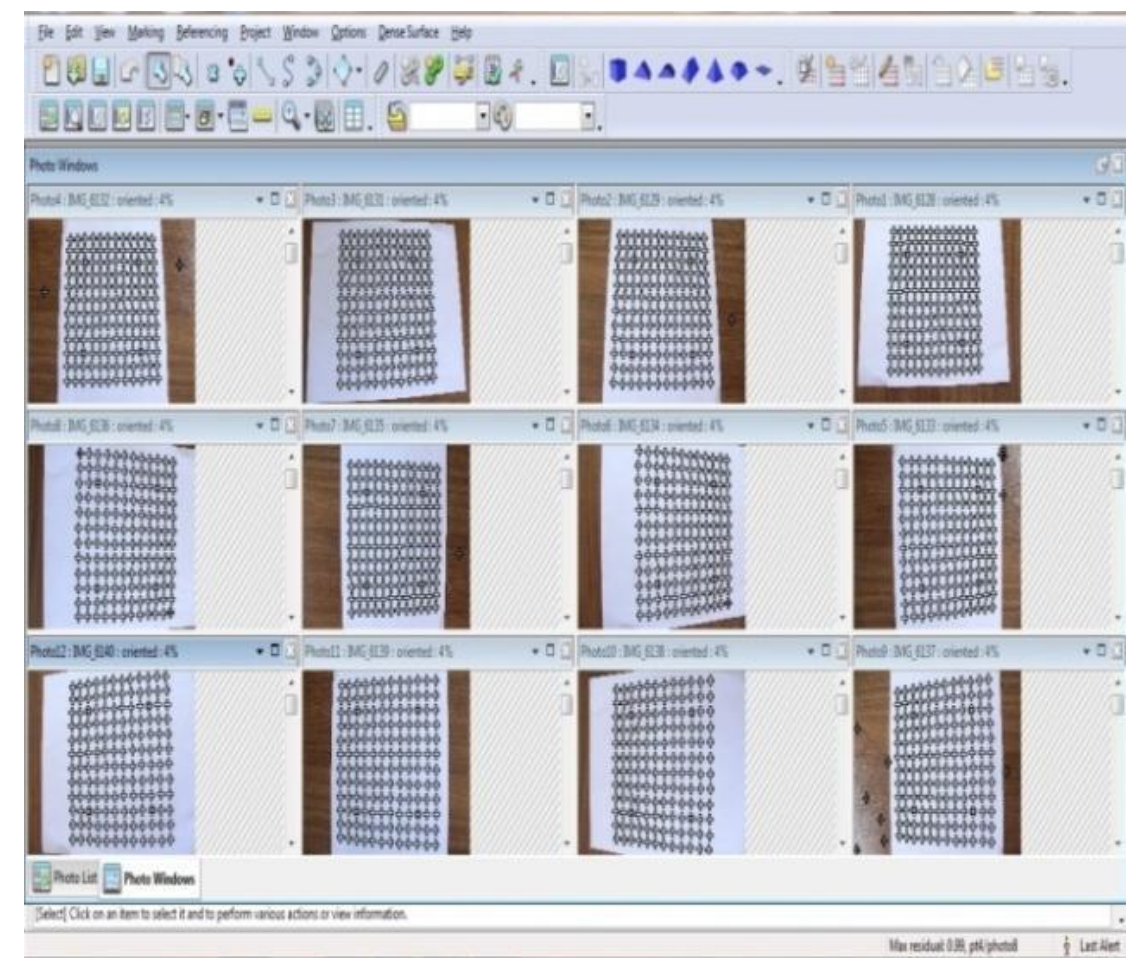

Figure 4. The camera calibration process

Table 2. Camera calibration parameter of Canon EOS650D

\begin{tabular}{|l|c|}
\hline \multicolumn{2}{|c|}{ Camera calibration parameter } \\
\hline Focal length & 18.6907 \\
Pirincipal point & $(11.4264,7.5369) \mathrm{mm}$ \\
Sensor format & $(22.7494,15.1638) \mathrm{mm}$ \\
Distortion parameter: $\mathrm{K}_{1}$ & 0.0005327 \\
Distortion parameter: $\mathrm{K}_{2}$ & -0.000001142 \\
Distortion parameter: $\mathrm{P} 1$ & -0.00004736 \\
Distortion parameter: $\mathrm{P}_{2}$ & 0.0041125 \\
\hline
\end{tabular}


The Sircalı Masjid has a different architecture. The architectural structure, called the Turkish triangle, is provided by the transition from a square shaped building element to a triangular element under a single-dome (Figure 5).

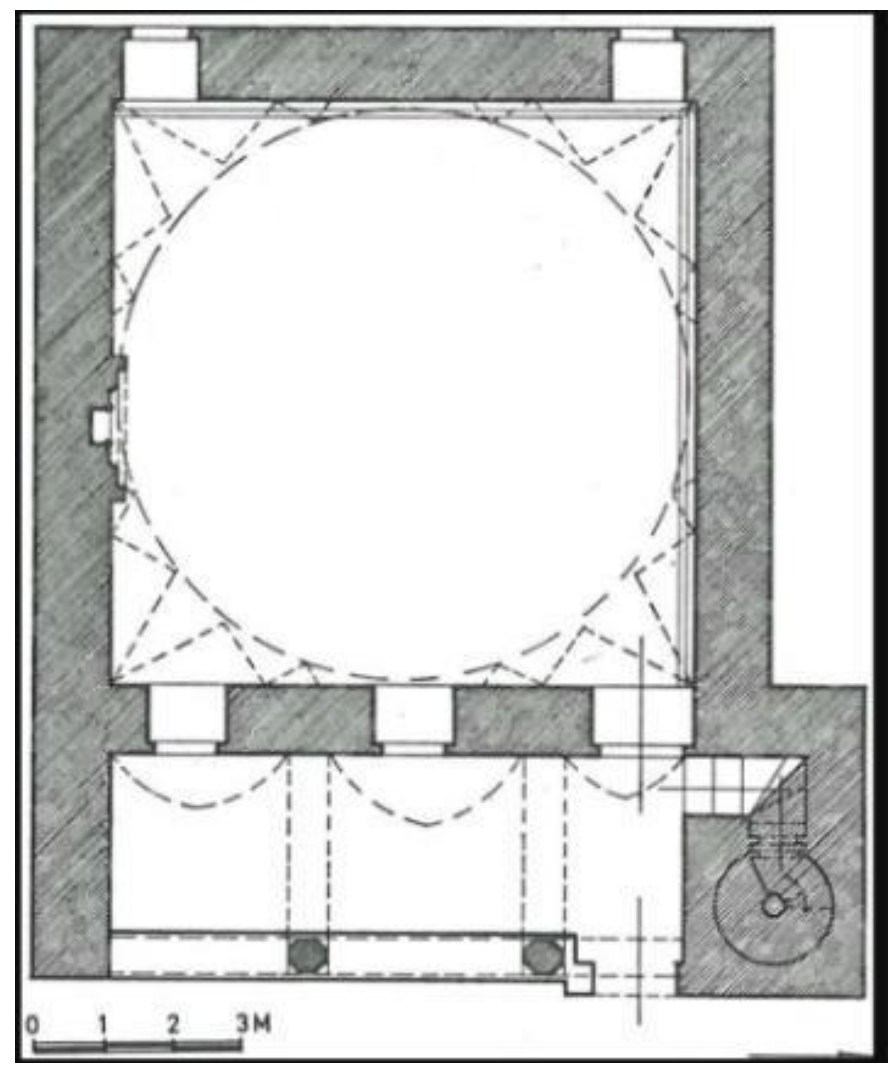

Figure 5. The top view of Sircalı Masjid

Due to the square plan of the mosque and the small size (approximately $6.85 \mathrm{~m}^{*} 6.85 \mathrm{~m}$ ), the indoor photographs were taken by calibrated camera with good measurement planning from different angles. It was noted that all images must have overlap area with each other. To estimate coordinates of points on any object or surface on overlapping image pairs, camera position and orientation information must be known. These are known as exterior orientation which can be determined if at least three control points are available in the overlapping image area. The control points, that defines relation between image and object coordinate system, is needed to find out these parameters. It was paid to attention to distribute control points on the brick surface homogenously and determine them easily via the photographs (Figure 6). In the study, the control points selected on brick surfaces measured by Topcon OS-103 total station. 


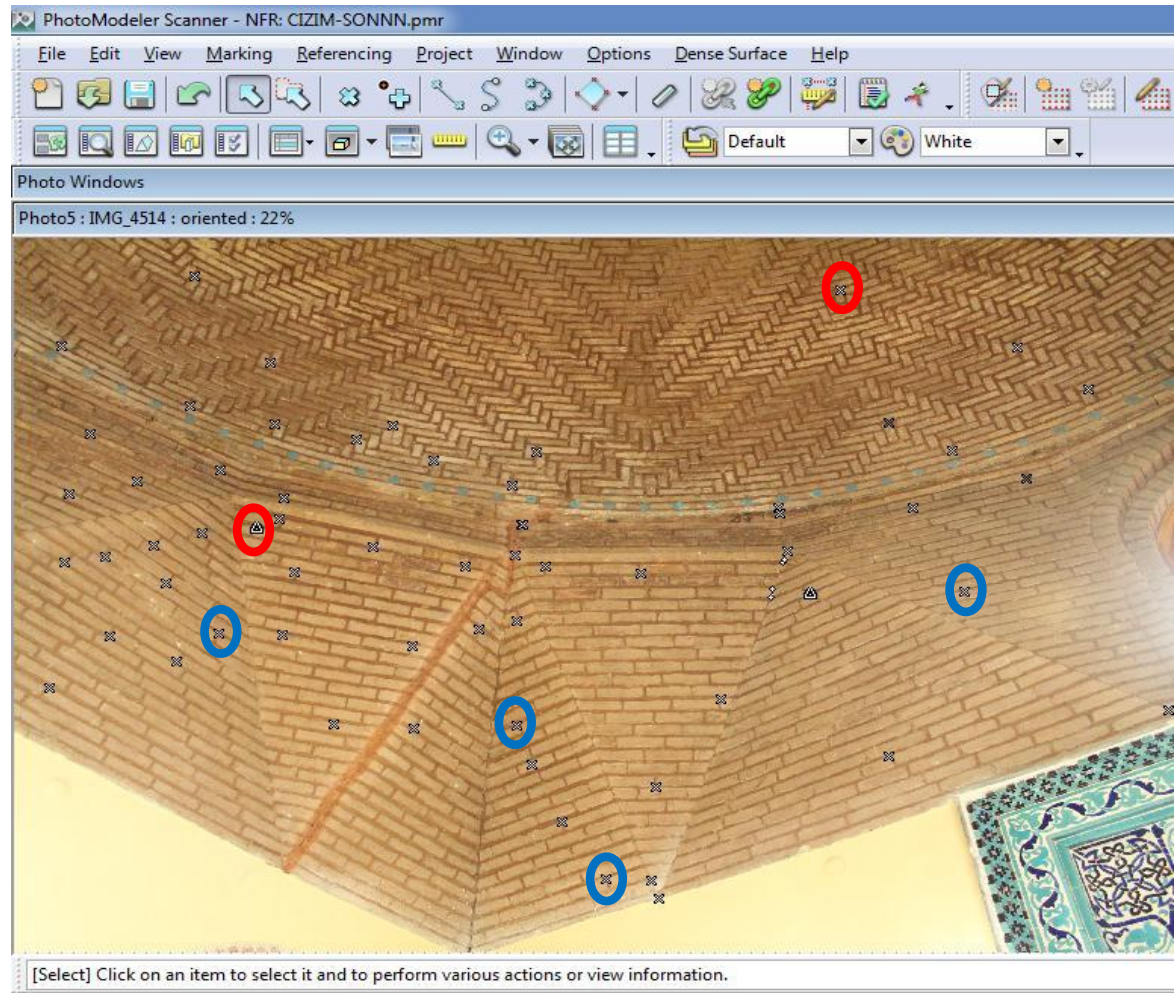

Figure 6. Distribution of the tie points and the control points

After the first 4 steps in the photogrammetric workflow given in Table 1 were completed, the photogrammetric evaluation process steps were started. The photogrammetric evaluation and indoor 3D modelling of Surçalı Masjid were made with Photomodeler software. The all images, camera calibration parameters, and the coordinates of the control points were transferred to Photomodeler Scanner Software. In order to extract 3D accurate information from 2D images, it is necessary to match stereo pairs with sufficient number of tie points and control points (red circle control points, blue circle tie points in Figure 6)

Photogrammetry uses the bundle block adjustment technique for directly computing the relations between the image and the object coordinates (Aicardi et al., 2018). The relationship between image and object coordinate system are computed using (ground) control point coordinates in the bundle block adjustment ,thus the camera position and orientation elements are resolved. As a result, of the adjustment, root mean square error of Sircalı Masjid Project is 4.87 pixels. According to this result, 3D drawings of the brick surface were realized in Photomodeler software. 

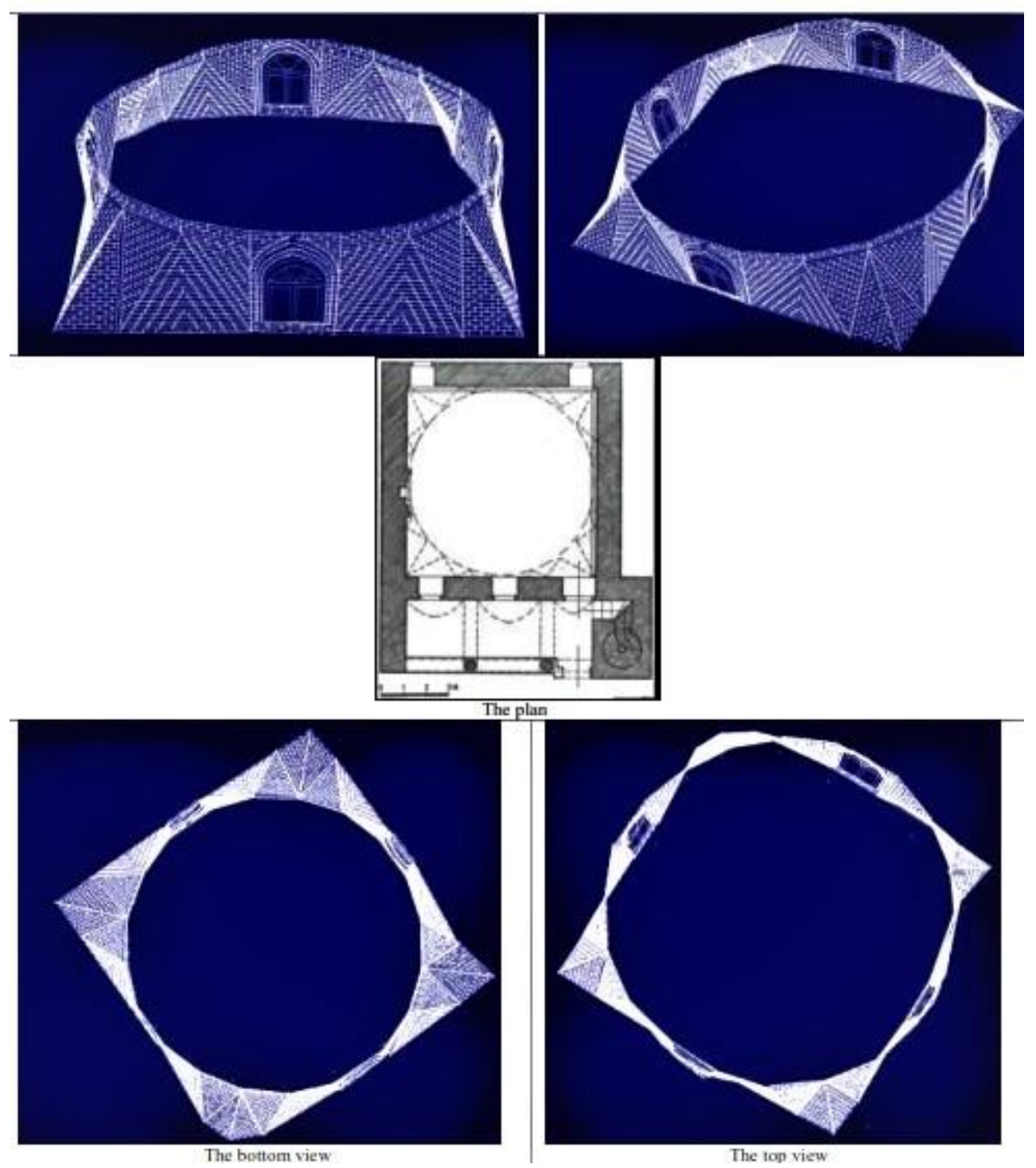

Figure 7. Three dimensional view of the dome transitional components

\section{CONCLUSION}

The aim of this study is to reveal the 3D the dome transitional components by measuring and evaluating it with photogrammetric methods of Sircalı Masjid which is a single domed mescit belonging to the Seljuk period. There are many historic mosques and masjids in our country with this feature.

3D modelling studies in the literature indicates that weight is given to external facade modelling. 3D models of similar structures have been previously created but there are no studies that modelled the transition elements that provide connection to the dome with modern techniques in interior space. The triangular band that makes a corner group as the dome transition members have been successfully achieved with close-range photogrammetry method. Also, the drawing and modelling of these geometric elements it shows that will be successfully modelled of the mosque dome with this technique. The terrestrial photogrammetry will shed light on the easily modelling and documentation of these structures. Besides, the pixel size of the used camera is important for the clarity of the photograph and it provides the easiness in drawing small objects such as bricks in the drawing stage. It has experienced problems due to the height of the building in the photo shooting stage. The angles of the photographs that were inclined due to the height make the adjustment phase difficult. 


\section{REFERENCES}

Aicardi, I., Chiabrando, F., Lingua, A., Noardo, F., 2018, “Recent Trends in Cultural Heritage 3D Survey: The Photogrammetric Computer Vision Approach", Journal of Cultural Heritage, Vol. 32 (2018), pp. 257-266

Karabork H., Karasaka, L., Yaldız, E., 2015, “A Case Study: Documentation Method with Close Range Photogrammetry of Muqarnas Which is to be an Ornamentation Type Specific to the Islamic Architecture", Procedia Earth and Planetary Science, Vol. 15, pp. 133-140.

Konyalı, İ. H., 1997, Konya Tarihi, Burak Matbaası, Ankara.

Nakazawa T, Samara A., 2014, "Three-dimensional Inline Inspection for Substrate Warpage and Ball Grid Array Coplanarity using Stereo Vision", Applied Optics, Vol. 53(14), pp. 3101-9. doi: 10.1364/AO.53.003101.

Önder, M., 1971, Mevlâna Şehri Konya, Konya Turizm Derneği.

Jebara, T., Azarbayejani, A., Pentland, A., 1999, "3D structure from 2D motion" IEEE Signal Processing Magazine, 3D And Stereoscopic Visual Communication, Vol.16.

Turan, Ş.N., 2018, Türk Mimarisinde Kullanılan Kubbeye Geçiş Elemanları; XIII. Yüzyıl Anadolu Selçuklu Dönemi Konya Mahalle Mescitleri Örneğ", Yüksek Lisans Tezi, NEÜ, FBE, Yayımlanmamış Yüksek Lisans Tezi

Turan, Ş.N., Yaldız, E., 2018, “XIII. Yüzyıl Konya Mahalle Mescitlerinde Kullanılan Kubbeye Geçiş Elamanları", Türk-İslam Medeniyeti Akademik Araştırmalar Dergisi, Cilt:13, Sayı: 26,2018-Yaz 